\title{
Yine Bir Salgın, Yeni Bir Salgın
}

\author{
ARUS YUMUL* \\ arus.yumul@bilgi.edu.tr \\ ORCID ID: 0000-0002-7783-2652
}

\begin{abstract}
Öz: Dünya tarihi bir anlamda çok sayıda can kayıplarına neden olan salgınların da tarihidir. Aşıların ve diğer bilimsel, tıbbi ve teknolojik müdahale ve inovasyonların sağladiğı tüm olumlu değişiklik ve ilerlemelere rağmen tarihsel tanıkliklar gösteriyor ki en azından iki bin beş yüz yıldır salginlar ve ölüm karşısında insanın savunmasızlı̆̆, çaresizliği, hastalık ve ölümle başa çıkma yolları ve -kişiden kişiye farklllık gösterse de- temel tepkileri değişmemektedir. Bu makale, tarihteki salgınlardan Atina Salgını (M.Ö. 430), Justiniyanus Veba Salginı (541-542), Kara Ölüm (1347-1351) veya Büyük Veba Salginı ve onunla bağlantılı olduğu düşünülen Büyük Londra Salgını (1665-1666), Fas Veba Salginı (1799) ve İspanyol Gribini (1918-1920) ilk elden ve yaşayanların tanıkliklarından yola çıkarak ele alıyor. Sonuçta, farklı dönem ve farklı şartlarda yaşanan bu salgınların benzer davranış kalıplarına yol açtığın gösteriyor.
\end{abstract}

Anahtar kelimeler: Salgın, Edebiyat, Tepkiler, Önlemler, Ölüm

\section{Giriş̧}

Dünya bugüne dek büyüklü küçüklü pek çok salgın hastalığa tanıklık etti, bundan sonra da bu tanıklığını sürdürecekmiş gibi gözüküyor. Bu makale bu salgınların belli başlılarına dikkat çekmekte, tanık-yazarların gözüyle her salgında tekrar eden insan tepkilerini, alınan ve alınmayan tedbirleri, hastalık ve ölümle başa çıkma yollarındaki benzerlik ve benzersizlikleri ele almaktadır. Makale şu salgınları konu edinmektedir: Atina Salgınını (M.Ö.430); Justiniyanus Veba Salgınını (541-542); Kara Ölüm (1347-1351) veya Büyük Veba Salgınını; Büyük Londra Salgınını (1665-1666), Fas Veba Salgınını (1799) ve İspanyol Gribini (1918-1920). Bu salgınların tanıkları sırasıyla, Thukydides; ${ }^{1}$ Kayserili Prokopios ${ }^{2}$ ve Efesli Yuhanna; ${ }^{3}$ Gi-

\footnotetext{
* Prof. Dr., İstanbul Bilgi Üniversitesi, Sosyal ve Beşeri Bilimler Fakültesi, Sosyoloji Bölümü.

${ }^{1}$ Thucydides, The History of the Peloponessian War, çev., Henry Dale, New York: Harper \& Brothers, 1878.

2 Procopius, History of the Wars, Books I \& II, çev., H. B. Dewing, Londra: William Heinemann, 1914; Procopius, History of the Wars, Books III \& IV, çev., H. B. Dewing, Londra: William Heinemann, 1916. 3 "John of Ephesus describes the Justinianic Plague", haz., Roger Pearse, erişim 3 Ocak, 2021, https://www.roger-pearse.com/weblog/2017/05/10/john-of-ephesus-describes-the-justinianic-plague.
} 
ovanni Boccacio ${ }^{4}$ ve Marchione di Coppo Stefani; ${ }^{5}$ Daniel Defoe ${ }^{6}$ ve Samuel Pepys; ${ }^{7}$ James G. Jackson; ${ }^{8}$ Suryakant Tripathi Nirala ${ }^{9}$ ve John O’Hara'dır. ${ }^{10}$

Thukydides'in Atinalılar ile Spartalılar arasındaki Peloponnesos Savaşları'nı anlattığı kitabı, savaş sürerken ortaya çıkan salgını; Bizans tarihçisi Prokopios’un Savaşların Tarihi yapıtı yazarın Jüstinyanus Salgını sırasında Bizans'ın başkenti Konstantinopolis'te yaşayıp gördüklerini; Efesli Yuhanna'nın Kilise Tarihi adlı eseri, aynı salgın hakkındaki yazarın izlenimlerini; Giovanni Boccaccio'nun 1348-1351 yılları arasında yazdığı Decameron Hikayeleri ve Marchione di Coppo Stefani'nin Floransa Tarihi, 1384 yılında "İtalya'nın en güzel şehirlerinden Floransa'da" hüküm süren "korkunç veba salgınını"11; Daniel Defoe'nun 1722 yılında, amcası H.F’nin (Henry Foe) günlüğünden yola çıkarak yazdığı Veba Yılı Günlüğü ise Büyük Londra Salgını'nı anlatır. Samuel Pepys'in 1660-1669 yılları arasında tuttuğu günlüğü de yine bu salgınla ilgili yazarın ilk elden gözlem ve tanıklığını içerir. 1799'da Fas'taki veba salgınını, o sırada Mogador'da yaşayan Avrupalı tüccar James G. Jackson kaleme alır. Hint şairi Suryakant Tripathi Nirala, otobiyografik kitabı A Life Misspent'te Hindistan'ı kasıp kavuran İspanyol Gribi'yle ilgili anılarını kısa ama etkili bir dille yansıtır. Pennsylvania'da Gibbsville adını verdiği madencilik bölgesindeki salgını doktor babasıyla gözlemleyen Amerikalı yazar John O’Hara, İspanyol Gribi ile ilgili deneyimlerini kurguladığı yarı biyografik öyküsü Doktor'un Oğlu'nda aktarır.

\section{İnsanın Kavrayışını Aşan Salgınlar}

Thukydides'in eşi görülmemiş büyüklükte "hiçbir yerde yaşanmadığg kadar can kaybına"12 yol açtığını söylediği Atina Salgını ${ }^{13}$ M.Ö. 430 baharında patlak verir. Etiyopya'da başlayan salgın "buradan Mısır ve Libya'ya ve Kral'ın ülkesine [İran]" ilerler. Oradan Yunan dünyasına geçer. Atina ile Sparta arasındaki Peloponessos Savaşı'nın başlamasından kısa bir süre sonra Pire Limanı'ndan Atina'ya ulaşır. Pireliler, Spartalıların su kaynaklarını zehirlediklerini iddia ederler. ${ }^{15}$ Bugünkü terimlerle söyleyecek olursak, biyolojik savaştan şüphelenirler. Perikles, savaş nedeniyle kırsal kesimdeki halkı Atina'nın yeni inşa edilen surlarının arkasına çekilmeye ikna ederek ${ }^{16}$ istemeden de olsa salgının yayılmasını hızlandırır; taşradan

\footnotetext{
${ }^{4}$ Giovanni Boccaccio, The Decameron. New York: Printed for the Trade, 1899.

${ }^{5}$ Marchione di Coppo Stefani, "The Florentine Chronicle", Fordham University, erişim 8 Ocak, 2021, https://sourcebooks.fordham.edu/med/marchione.asp.

${ }^{6}$ Daniel Defoe, A Journal of the Plague Year, Londra: Cassel, 1909.

${ }^{7}$ Samuel Pepys, The Diary of Samuel Pepys, Londra: Macmillan, 1905.

${ }^{8}$ James Grey Jackson, An Acount of Timbuctoo and Housa, Territories in the Interior of Africa, Londra: Longman, Hurst, Rees, Orme, Brown, 1820.

${ }^{9}$ Suryakant Tripathi Nirala, A Life Missspent, çev., Satti Khanna, New York: Harper Perennial, 2016.

${ }^{10}$ John O'Hara, The Doctor's Son, New York: Library of America: E-Book Classics, 2016.

${ }^{11}$ Boccaccio, Decameron, s.1.

12 Thucydides, The History, s.119.

13 Thukydidies hastalığın fiziksel semptomlarını detaylı bir şekilde aşama aşama kaydetmiş olsa da (Thucydides, The History, s.119-120) hastalığın tanımlanmasında bugüne kadar fikir birliğine varılamadı. Tifüs, tifo ve çiçek hastalığı en çok tercih edilenler olsa da farklı hastalıkların salgına sebep olduğu öne sürüldü.

${ }^{14}$ Thucydides, The History, s.119.

${ }^{15}$ Thucydides, The History, s.119.

16 Thucydides, The History, s.100.
} 
şehre akın eden halk mevcut felaketi daha da ağırlaştırır. Şehre gelen bu kalabalığın, "kendilerine ait bir evlerinin olmaması" ve "yılın bu sıcak mevsiminde boğucu kulübelerde yaşamaları" nedeniyle ölüm oranları hızla artar. ${ }^{17}$ Hastalığın nasıl ortaya çıktığına dair kural olarak akla yatkın bir sebep yoktur; semptomlar sağlığı yerinde olan kişilerde aniden ortaya çıkmaktadır. ${ }^{18}$ Güçlü ve zayıf bünyeler hastalığa aynı derecede dayanıksızdır; salgın bu iki bünye sahibini de silip süpürmüştür. ${ }^{19}$ Doktorlar mahiyetini, dolayısıyla nasıl tedavi edeceklerini bilmedikleri bu hastalıkla baş edemezler, salgını kontrol etmekte yetersiz kalırlar. Dahası, hastalarla sık temas ettiklerinden dolayı doktor ölümleri çok yüksektir. ${ }^{20}$ Hastalık bulaşıcıdır. ${ }^{21} \mathrm{Ne}$ tıp "ne de bir başka insan sanatı" hastalığın tedavisinde işe yaramaz. "Tapınaklardaki dualar, kehanetler ve benzerleri de eşit derecede beyhude" kalır. ${ }^{22}$ Derde deva olacak kesinleşmiş bir tedavi şekli yoktur; "zira bir hastaya iyi gelen, diğerine zarar vermektedir." ${ }^{33}$ Atina'da hayvanlar da tehlike altındadır. Yırtıcı kuşlar ve vahşi hayvanlar, çoğunlukla gömülmemiş halde yatan cesetlerle temas etmekten imtina eder; temas edenler de oracıkta can verir. ${ }^{24}$ Fas'ta kuşlar, adeta hastalanmamak için insanların yaşadıkları yerlerden kaçarken sırtlanlar cesetleri yemek için mezarlıklara üşüşür. ${ }^{25}$

Floransa'da sadece insanlar değil "köpekler, kediler, tavuklar, öküzler, eşekler, koyunlar" da vebadan ölür. ${ }^{26}$ Hastalığın yayılma hızı ve bulaşıcılığı azımsanmayacak büyüklüktedir. Hastalık sadece hasta kişiyle konuşmakla veya yakın temas kurmakla değil hastanın kıyafetlerine, yediği yemeğe veya daha önce ellediği herhangi bir nesneye dokunmakla da bulaşır. ${ }^{27}$ Enfekte olan veya salgından ölen kişinin herhangi bir eşyasına dokunan hayvanlar da kısa sürede ölür. Vebadan ölen yoksul bir adamın sokağa atılan paçavralarına yemek bulmak umuduyla burunlarını sürten iki domuz, bir saat içinde havale belirtileri gösterip temas ettikleri paçavraların üzerine yığılarak can verir. ${ }^{28}$ Boccacio'ya göre, birkaç yıl önce doğuda başlayan salgın, sayısız can aldıktan sonra hiç duraksamadan batıya doğru ilerler. Hastalığın Floransa'ya girmesini engellemek için insan bilgeliği ve öngörüsünün aldığg hiçbir tedbirin faydası olmaz. Ne şehrin kirden arındırılması ne hastalığa yakalananların şehre girmesinin yasaklanması ne yayınlanan çok sayıda talimat ne de Tanrı'nın lütfunu dilemek için edilen bireysel ve toplu dualar işe yarar. ${ }^{29} 1348$ yılının ilkba-

\footnotetext{
${ }^{17}$ Thucydides, The History, s.122.

${ }^{18}$ Thucydides, The History, s.119.

${ }^{19}$ Thucydides, The History, s.121.

${ }^{20}$ Thucydides, The History, s.119.

${ }^{21}$ Tıpçı olmayan Thukididies, hastalıkların enfekte bir kişiden diğerine bulaştığını gözlemlerken tıp alanındaki çağdaşları hastalıkları miasma teorisi ile açıklıyordu. Thukidides hastalığı geçirenlerin hastalığa karşı bağışıklık kazandığını da gözlemlemişti (Thucydides, The History, s. 121).

${ }^{22}$ Thucydides, The History, s.119.

${ }^{23}$ Thucydides, The History, s.121.

${ }^{24}$ Thucydides, The History, s.120-121.

${ }^{25}$ Jackson, An Acount, s.173-174.

${ }^{26}$ Stefani, "The Florentine".

${ }^{27}$ Boccaccio, Decameron, s.2.

${ }^{28}$ Boccaccio, Decameron, s.2.

${ }^{29}$ Boccaccio, Decameron, s.1.
} 
harında, veba şehre girip korkunç yüzünü gösterir. Mart ile Temmuz ayları arasinda Floransa'da en az yüz bin kişi ölür. ${ }^{30}$ Boccacio, "Galen, Hipokrat ve Asklepios'un" sağlıklı olduklarına şahitlik edeceği hayatlarının baharındaki pek çok genç kadın ve erkeğin, "sabah hayattaki arkadaşlarıyla kahvaltı ederken, akşam öteki dünyada ölmüş arkadaşlarıyla" yemek yediğini ${ }^{31}$ söyler. Hastalığın tedavisinde hiçbir doktor reçetesi, hiçbir ilaç, hiçbir tıbbi bilgi işe yaramaz. Etkinliği kanıtlanmış bir tedavi yöntemi yoktur; zira hekimler hastalığın nedeni gibi tedavisi hakkında da fikir oluşturamazlar. ${ }^{32}$ Stefani, Floransa'da hastalığa karşı "ne hekimlerin ne de ilaçların" etkili olduğunu söyler; bu hastalık daha önce bilinmediğinden veya doktorların bilgisi dışında kaldığından herhangi bir tedavisi yoktur; dolayısıyla herkes korku içinde ve ne yapacağını bilemez haldedir. ${ }^{33}$ Insan aklı salgınla başa çıkmakta yetersiz kalır. Hakim duygu çaresizliktir. Aklı yetersiz kılan benzer bir acz duygusunu, "Bu felaketi kelimelerle ifade etmek veya akıl yoluyla anlamak imkansızdır"34 diyen Prokopios'un satırlarında da görürüz. Tüm insan ırkını yok olma tehlikesiyle karşı karşıya bırakan veba, Mısır’’n Pelusium şehrinde başlar ve oradan tüm dünyaya yayılır"35: "Yeryüzünün herhangi bir köşesinin kendisinden kaçabileceğinden adeta korkarcasına dünyanın her iki yönüne doğru ilerledi. İnsanların yaşadığı ne bir adayı ne bir mağarayı ne de bir dağ sırtını ihmal etti." ${ }^{36}$ Prokopios'a göre veba bir ülkeden diğerine geçerken adeta bir plana göre hareket ediyor, "her ülkede belirli bir süre oyalanıyor", vereceği zararı veriyor, eğer herhangi bir bölgeye fazla zarar vermeden çekip gitmişse daha sonra tekrar geri geliyor, "adaletli ve tam" 37 sayıya ulaşmadan o diyardan ayrılmıyordu. Efesli Yuhanna bu salgının bir örüntüye göre hareket ettiğini, uğradığ 1 her bölgede normal seyrini izlemeden -yani oraya sağlam bir şekilde köklenmeden- başka bir bölgeye ilerlemediğini söyler. ${ }^{38}$

Bizans'ta hastalık dört ay sürer. ${ }^{39}$ Salgın, başlangıçta birkaç kurban alırken kısa sürede ivme kazanır. İlk günler ölümler her zamankinden biraz daha fazladır; sonra bu sayı artar ve zamanla günde beş bine, on bine, hatta daha fazlasına ulaşır. ${ }^{40}$ Hastalık İstanbul'da farklı kişilerde farklı seyrederken tedavi yöntemleri de farklı hastalarda farklı sonuçlar verir. Banyo yapmak kimi hastaya iyi gelirken, kimi hastaya zarar vermektedir. ${ }^{41}$ Hiçbir tedavi görmeyenlerin çoğu beklendiği gibi hayatını kaybederken bir bölümü "akla aykırı bir şekilde" iyileşir. ${ }^{42}$ En ünlü doktorların kısa sürede öleceğini öngördükleri pek çok hasta iyileşirken hastalıktan kurtulacağını tahmin ettikleri pek çok hasta ise kısa sürede yaşamını yitirir. ${ }^{43}$ Hastalık kendisini

\footnotetext{
${ }^{30}$ Boccaccio, Decameron, s.6.

${ }^{31}$ Boccaccio, Decameron, s.2.

${ }^{32}$ Boccaccio, Decameron, s.2.

${ }^{33}$ Stefani, "The Florentine".

${ }^{34}$ Procopius, History, I \& II, s. 463.

${ }^{35}$ Procopius, History, I \& II, s.453.

${ }^{36}$ Procopius, History, I \& II, s. 455 .

${ }^{37}$ Procopius, History, I \& II, s.455.

38 "John of Ephesus".

${ }^{39}$ Procopius, History, I \& II, s.465.

${ }^{40}$ Procopius, History, I \& II, s.465.

${ }^{41}$ Procopius, History, I \& II, s.463.

${ }^{42}$ Procopius, History, I \& II, s.463.

${ }^{43}$ Procopius, History, I \& II, s.463.
} 
ne dünyanın belirli bir bölgesiyle, ne belirli gruplarla, ne de yılın herhangi bir mevsimiyle sınırlar; "kimilerini yaz mevsiminde, kimilerini kışın, kimilerini ise yılın başka bir döneminde enfekte eder," ${ }^{44}$ cinsiyete ya da yaşa aldırmadan herkesi etkisi altına alır. ${ }^{45}$ Semptomlar ve hastalığın yayılma şekli gibi salgının nedenleri de geçerli bir açıklamaya izin vermeyecek kadar tutarsızdır; dolayısıyla insan muhakemesini aşar. ${ }^{46}$ Prokopios'a göre bu konuda tek mantıklı yaklaşım, salgını Tanrıya atfetmektir. ${ }^{47}$ Efesli Yuhanna'ya göre de bu salgın ilahi gazabın bir tezahürü ve bir tövbe çağrısıdır. ${ }^{48}$

Veba, Londra'da adeta tüm ilaç ve tedavilere meydan okur, doktorlara varıncaya kadar herkesi ele geçirir. ${ }^{49}$ Burada da bulaşmanın doğasını keşfetmek veya önlemek her türlü insan becerisini aşar; ${ }^{50}$ hastalığın tedavisi hakkında fikir birliği oluşmadığından herkes farklı şeyler söyler. ${ }^{51}$ Londralılar, veba şehre gelmeden salgının varlığından söylenti yoluyla haberdar olmuşlardır. Salgın, Pepys’in günlüğüne ilk kez Ekim 1663'te girer. 31 Ekim'de günlüğüne, Amsterdam'da büyük bir salgının patlak verdiğini ve İngiltere'ye ulaşmasından korktuğunu yazar. ${ }^{52}$ Hollanda'daki salgının hem karada hem de denizde büyüdügüüne dair haberler 1664 yılı boyunca Pepys'in günlüğünde yer bulur. Salgın, Pepys'in ve Londralıların endişelerini haklı çıkararak şehre ulaşır. Şehir hazırlıksız yakalanmıştır. 1664 yılının son aylarında baş gösteren ölümlere Londralılar gereken önemi atfetmemiş, vebanın şehre gelmeyeceğine dair sarsılmaz inançlarını aylar boyunca korumuşlardır. ${ }^{53}$ Hükümet ise daha 1663'te, vebanın Hollanda'ya ulaştığından haberdar olmuş, yaklaşan tehlikeyle ilgili çeşitli toplantılar yapmış, ama bu bilgiyi halkla paylaşmaktan imtina etmiştir. ${ }^{54}$ Hastalık, 1664 yılının sonları ile 1665'in başlarında, ilk olarak şehrin surlarının dışındaki fakir bir bölge olan St. Giles'da ortaya çıkmıştır. ${ }^{55}$ Pepys, 30 Nisan 1665 'te şehirdeki iki üç evin kapatıldığından bahsedildiğini ve bunun büyük bir korkuya neden olduğunu söyler. ${ }^{56}$ Mayıs ayında, gittiği kahvedeki insanlardan vebanın şehirde yayıldığını duyar. ${ }^{57}$ Haziran ayının başında ilk kez kendi gözleriyle "kapıları kırmızı haçla işaretlenmiş" ve üzerinde "Rab bize merhamet et!" yazan "kapanmış" evleri görünce iyiden iyiye kaygılanır. ${ }^{58}$ Ölü sayısı 13 Haziran'da 700'ü, 20 Haziran' da 1000'i, 10 Ağustos'ta 3000'i aşar. ${ }^{59}$ Hastalık önce şehrin uzak bir bölgesinde ortaya çıkmış, kısa sürede şehre yayılmış, ardından komşular, arkadaşlar, tanıdıklar hastalanmaya ve ölmeye başlamıştır. Pepys, bu durumu günlüğüne “Garsonum zavallı Payne’in bir çocuğunu gömdügünü ve kendisinin de ölmek

${ }^{44}$ Procopius, History I \& II, s.453.

${ }^{45}$ Procopius, History, I \& II, s.453.

${ }^{46}$ Procopius, History I \& II, s.463.

${ }^{47}$ Procopius, History, I \& II, s.453.

48 "John of Ephesus".

${ }^{49}$ Defoe, A Journal, s.49.

${ }^{50}$ Defoe, A Journal, s.246.

${ }^{51}$ Pepys, The Diary, s.314.

${ }^{52}$ Pepys, The Diary, s.224.

${ }^{53}$ Defoe, A Journal, s. 9-13.

${ }^{54}$ Defoe, A Journal, s.9.

${ }^{55}$ Defoe, A Journal, s.11.

${ }^{56}$ Pepys, The Diary, s.342.

${ }^{57}$ Pepys, The Diary, s.314.

${ }^{58}$ Pepys, The Diary, s.316.

${ }^{59}$ Pepys, The Diary, s.326-327; 334. 
üzere olduğunu duymak, geçen gün oradaki durumu öğrenmek için Degenhams'a gönderdiğim işçinin vebadan öldügünü duymak" sözleriyle kaydeder; kendisini her gün taşıyan kayıkçılardan birinin de vebadan öldüğünü öğrenir. ${ }^{60}$ Uzak bir endişe olarak başlayan salgın gittikçe yaklaşmıştır.

Jackson'un "en ölümcül türlerinden biri"61 olarak tanımladığı veba Fes şehrinde 1799 yılında ortaya çıkar. Nerede ve nasıl ortaya çıktığına ve nedenlerine dair farklı fikirler ortaya atılır. ${ }^{62}$ "Bu benzersiz felaket" giderek hızını arttırır, vaka sayısı giderek yükselir. ${ }^{63}$ Fes üzerinden Mogador'a ulaşır. Jackson'a göre salgını şehre İmparatorun ordusunun şehirden geçen bir tümeni getirir; ölen askerler, tümenin kamp yaptığı alandaki çadırlarda gizlice gömülür ki halk bu ölümlerden haberdar olmasın ve hastalık kapmaktan çekinip orduya erzak sağlamaktan vazgeçmesin. ${ }^{64} 10000$ nüfuslu kentte her gün kırk ile elli arasında kişi ölür ve bu sayı her geçen gün artarak 100'e ulaşır ${ }^{65}$ Hastalık önce genç, sağlıklı ve güçlü erkekleri, sonra kadın ve çocukları, en sonra da zayıf, hasta ve yaşliları ele geçirir; semptomlar bir hastadan diğerine farklılık göstermektedir. ${ }^{66}$ Burada da ilaç ve hekimlere başvurmak bir işe yaramaz. Sonunda insanlar çare aramaktan vazgeçerler. Bu "korkunç bela" tarafından ele geçirilenler artık hayatta kalma umutlarını tamamen yitirmişlerdir. ${ }^{67}$

Hindistan'da grip salgını başladığında Nirala, Bengal'dedir. Karısının ağır hasta olduğunu bildiren bir telgraf alır. Eşini görmek için kayınpederinin Dalmau'daki evine gider. Ancak eve vardığında karısı zaten hayatını kaybetmiştir. ${ }^{68}$ Karşılaştı̆̆ 1 tek ölüm bu değildir. Karısına bakmak için gelen kuzeni, hastalığı kapıp köyüne geri döner ve orada vefat eder. Ailenin birçok diğer üyesi de hastalığa yenik düşer. O kadar çok ölüme tanıklık eder ki "Ailem göz açıp kapayıncaya kadar ortadan kayboldu. Tüm ortaklarımız, işçilerimiz öldü”69 diye yazar. Nirala, duygularını, "Kelimeler manzaranın ne kadar acınası ne kadar çaresiz ne kadar hassas olduğunu anlatamıyor"; "Hangi yöne dönsem karanlığı gördüm” sözleriyle ifade eder. ${ }^{70}$

\section{Tedbirler}

Hastalığın güçlü bulaş riski karşısında Floransalılar, hasta ve hastanın eşyalarından kaçmaya çalışır. ${ }^{11}$ Komşu, akraba ve arkadaşlar birbirlerine el uzatmaz, birbirinin yanına yaklaşmaz. Kardeş kardeşi, karı kocayı, ana baba çocuklarını terk eder. ${ }^{72}$ Salgın ikliminde sosyal kodlar hayatta kalma dürtüsünün ağırlığı altında çözülür. Bugünün terimleriyle söyleyecek olursak, sosyal mesafeleşmeye duygusal mesafeleşme eşlik eder. Birçok kişi açlıktan ve bakımsızlıktan yapayalnız ölür. Evde biri

\footnotetext{
${ }^{60}$ Pepys, The Diary, s.342.

${ }^{61}$ Jackson, An Acount, s.159.

${ }^{62}$ Jackson, An Acount, s.166.

${ }^{63}$ Jackson, An Acount, s.167.

${ }^{64}$ Jackson, An Acount, s.158.

${ }^{65}$ Jackson, An Acount, s.160-161.

${ }^{66}$ Jackson, An Acount, s.170.

${ }^{67}$ Jackson, An Acount, s.168.

${ }^{68}$ Nirala, A Life, s.83.

${ }^{69}$ Nirala, A Life, s.84.

${ }^{70}$ Nirala, A Life, s.84-85.

${ }^{71}$ Boccaccio, Decameron, s.2.

${ }^{72}$ Boccaccio, Decameron, s.3.
} 
hastalandığında diğerleri, "Ben doktora gidiyorum" diyerek "sakin bir şekilde kapıdan çıkıyor ve bir daha geri dönmüyordu."73 Kimse hastalık olan eve girmek istemez, hatta bir hastanın evinden çıkan sağlıklı insanlarla yani temaslılarıyla da ilişkiye girmekten çekinir. Hastalananların çoğu tek başına ölür, cesetleri kokuşur. Kokuyu alan komşuları onları kefenleyip defnedilmek üzere dışarı çıkarırlar. Ev açık kalsa da hastalığı kapma korkusundan "kimse evdeki eşyalara dokunmaya cesaret edemez." ${ }^{\prime 4}$ Atina'da "Bazıları ihmalden", "bazıları ise her türlü ilginin odağında" ölmüştür. ${ }^{75}$ Hastalanmak korkusuyla arkadaşlarından kaçan, ailelerini dışlayanlar olduğu gibi sonunda kendileri hastalanana kadar hastaları ziyaret edenlere de rastlanir. ${ }^{76}$

Londra'da herkes hastalarla temas etmekten sakındığından vebaya yakalananlar "komşularının kendilerinden uzak durup sohbetten kaçınmasını" önlemek için durumlarını gizlemeye çalışırlar. ${ }^{77}$ Burada da kendini koruma ana kuraldır. Yaklaşan ölüm tehlikesi insanların birbirlerine duyduğu sevgi ve ilgiyi, şefkat ve acımayı ortadan kaldırır; çocuklar ebeveynlerinden, ana babalar çocuklarından kaçar. ${ }^{78}$

Mogodor'da Avrupalı tüccarlar salgın boyunca evlerine kapanır. Yazarın gözlemlerine göre, hastalık mesafe ihlalinden ziyade hastanın nefesini solumak veya enfekte kişiye dokunmakla bulaşıyordu. ${ }^{79} \mathrm{Bu}$ yüzden kendi evinde, mutfak ile yemek odası arasına, diğer taraftaki kişinin nefesini solumayı önleyecek yükseklikte bir bölme yaptırır, uşaklarla yakın temasa girmeden yemekleri bu bölmeden alır. Yemek odasına bir uçtan bir uca uzanan bir masa koyar, masanın bir tarafına kendisi oturur, diğer tarafına ziyaretçilerini oturtur, bu şekilde onlarla yakın temastan kaçınır ${ }^{80}$ Kimsenin elini sıkmaz, tokalaşmak isteyenlere de salgın bitene kadar kimseyle el sıkışmayacağını söyler.

Sosyal mesafeleşme önleminin ötesinde Floransalılar salgın karşısında farklı yollar benimsemişlerdir. Bazıları tüm aşırılıklardan uzak kalarak, kararınca yiyip içerek, başkalarıyla ilişkiyi keserek, her türlü habere kulaklarını kapatarak ölçülü ve toplumdan uzak bir yaşamı tercih etmiş, hoşça vakit geçirmek için müzik gibi evde yapılabilecek aktivitelere yönelmişler, bazıları ise tavernalarda, salgın nedeniyle boş kalan evlerde bir araya gelerek kendilerini yiyip içmeye, gezip eğlenmeye, hayattan olabildiğince zevk almaya vermişlerdir. Bir kısım insan da bu iki aşırı yaşam tarzından uzak kalıp orta bir yolu tercih etmiştir. Bazıları ise -sanki Tanrı'nın gazabı onları gittikleri yerde bulmayacakmış ve sadece şehrin duvarlarının içinde kalanları imha edecekmiş gibi- hastalıktan korunmanın en etkili yolunun ondan kaçmak olduğunu düşünerek şehirden ayrılmışlardır. ${ }^{81}$ Ancak, bu farklı grupların her birinin arasında hastalığa yakalanıp ölenler olduğu gibi hastalığa yakalanmaktan

\footnotetext{
${ }^{73}$ Stefani, "The Florentine".

${ }^{74}$ Stefani, "The Florentine".

${ }^{75}$ Thucydides, The History, s.121.

${ }^{76}$ Thucydides, The History, s.121.

77 Defoe, A Journal, s.15.

${ }^{78}$ Defoe, A Journal, s.143.

${ }^{79}$ Jackson, An Acount, s.177.

${ }^{80}$ Jackson, An Acount, s.161.

${ }^{81}$ Boccaccio, Decameron, s.2-3.
} 
kurtulanlar da olmuştur. ${ }^{82}$ Şehri terk edip köylere gidenler, hastalık olmayan bölgelere hastalığı taşımışlar, var olan bölgelerde ise hastalığın artmasına neden olmuşlardır. Kimse güvende değildi, ancak gruplar halinde bir araya gelenler daha fazla risk altındaydı. Korkularından kurtulup biraz rahatlamak için her akşam bir araya gelip birlikte yemek yiyenlerden ya birkaçı hastalanıp ertesi akşamki yemeğe katılamazdı ya da o akşamın ev sahibi hastalanmış olduğundan yemek iptal edilirdi. ${ }^{83}$

1665 veba salgınında, Londralılar da Floransalılar gibi farklı sağkalım taktiklerine başvururlar. Özellikle zengin ve ayrıcalıklı kesim Londra'dan kaçar. Yollar kadın, erkek, çocuk, hizmetçi ve uşaklarla, bunların eşyalarını taşıyan yük arabaları, at arabaları ve yaylı arabalarla dolup taşar. Haziran sonunda insanlar şehirden vagonlarla kaçıyor, şehrin çıkış yollarında izdiham yaşanıyordu. ${ }^{84}$ Temmuz'da Ana Kraliçe Fransa'ya doğru yola çıkar; sarayın hademelerinden birinin karısı hastalanıp ölünce Kral ve Kraliçe şehri terk edip Milton'a gitmeye karar verirler. ${ }^{85}$ Londralıların bir diğer kesimi istif edebilecekleri ne varsa stoklayıp kendilerini ve ailelerini eve kapatır, salgın geçene kadar dışarı çıkmayıp, dışarısı ile tüm ilişkilerini keserler ${ }^{86}$ Esasen hekimlerin tavsiyesi de bu yöndedir: Herkesin kendisini ve ailesini eve kapatmasını, kimsenin dışarı çıkmamasını, pencere, perde ve panjurların sıkı sıkıya örtülmesini, odaların kükürt, barut, çamsakızı gibi maddelerle tütsülenmeden açılmamasını önerirler. ${ }^{87}$ Bazıları ise veba kendi sokaklarına veya evlerine ulaşıncaya kadar inatçı bir inkarı sürdürüp hiçbir şey olmamış gibi yaşamaya devam ederler. Floransa'da olduğu gibi Londra'da da kendilerini içkiye verip meyhane meyhane gezen, eğlenecek yer arayan ve ölümle alay edenlere rastlanır. ${ }^{88}$

Veba şehirde yayılmaya başlayınca Londra Belediyesi çeşitli tedbirler alır. ${ }^{89}$ Hastaların evlerine kapatılması kararlaştırılır. Hastalığın görüldüğü veya şüphelenildiği evler, sakinleriyle birlikte bir ay boyunca veya herkes iyileşinceye kadar tecrit edilir; enfekte olanların yanı sıra temaslıları da bulaş riski göz ardı edilerek, karantinaya alınır. Kapılarına bekçiler yerleştirilen bu kişiler bir nevi ev hapsindedir. Ancak birçok kişi yasağa uymak yerine bekçileri atlatıp evden çıkmanın bir yolunu bulur ve hastalığı başkalarına bulaştırır. Ailelerin gıda, ilaç gibi ihtiyaçlarını karşılamak, doktor veya hemşire çağırmak bekçilerin görevleri arasındadır; bir şartla ki bekçi kapının önünden ayrılırken ön kapıyı kilitlemekle kalmayacak, anahtarı da yanına alacaktır. Evde kalması gereken aileler anahtarın kopyasını çıkararak veya kilidi sökerek dışarı çıkarlar. Arka kapıları veya pencereleri kullanmak, bekçileri silahla tehdit etmek, onlara saldırıp şiddet kullanmak veya rüşvet vermek evden çıkmak için başvurulan diğer yollardır. ${ }^{90}$ Kahvehaneler, birahaneler, tavernalar daha sıkı kontrole tabi tutulur, insanların bir araya geldiği aktiviteler yasaklanır. ${ }^{91}$ Londra'da

${ }^{82}$ Boccaccio, Decameron, s.3.

${ }^{83}$ Stefani, "The Florentine".

${ }^{84}$ Pepys, The Diary, s.322.

${ }^{85}$ Pepys, The Diary, s. 322; 334.

${ }^{86}$ Defoe, A Journal, s.72.

${ }^{87}$ Defoe, A Journal, s.98.

88 Defoe, A Journal, s.82-83.

${ }^{89}$ Defoe, A Journal, s.55-62.

${ }^{90}$ Defoe, A Journal, s.66-70.

${ }^{91}$ Defoe, A Journal, s.61. 
insanlar en çok gündelik alışverişlerini yaparken enfekte olur ve hastalığı bu şekilde kapanlar evdekilere de bulaştırırlar: "İhtiyaçların tedariki için evden çıkma zorunluluğu büyük ölçüde şehrin mahvolması" ${ }^{92}$ demektir. Gerçi insanlar alışveriş sırasında alınabilecek her türlü tedbiri alırlar. Et alacak kişi eti kasabın elinden almak yerine çengelden kendisi çıkarır; kasap müşterisinden, parayı sirke dolu bir kaba koymasını ister. Müşteriler kasaptan para üstü almak zorunda kalmadan tam tutarı ödeyebilmek için yanlarında bozuk para bulundurur..$^{93}$

Floransa'da birçok kişi salgından korunmak amacıyla yanlarında şifalı bitkiler ve çeşit çeşit baharat taşır. ${ }^{94}$ Londra'da imkanları yeterli olanlar yanlarında şişe şişe koku ve parfüm bulundurmak dahil çeşitli tedbirler alırlar. ${ }^{95}$ Özellikle sağlam görünen asemptomatik taşıyıcıları öğrendiklerinde bitkisel profilaktikleri ağızlarında ve ceplerinde taşıyanların sayısı artar: "Doktorlar tehlikenin hasta kadar sağlıklıdan, yani görünüşte sağlıklı olandan da geldiği, ve kendilerini [hastalıktan] tamamen azade zanneden bu kişilerin çoğu zaman en ölümcülü oldukları konusunda" uyarınca çok sayıda kişi kendilerini eve kapatır ve yabancılarla konuşmak zorunda kaldıklarında, "ağızlarında her zaman koruyucular ve enfeksiyonu uzaklaştırmak için bezler" bulunur. ${ }^{96}$

\section{Kehanetler, Alametler, Hezeyanlar}

Kaygı ve endişeler, Londralıları "falcılara, kurnaz adamlara ve astrologlara"97 yönlendirir: "Başlarına ne geleceğini öğrenmek için" -kendilerinden para koparmak uğruna korkularını besleyip canlı tutan- "büyücülere, cadılara ve her türlü dolandırıcılara koştular." ${ }^{\prime 8}$ Şarlatanların, sahte ilaç satıcılarının, şifacıların verdiği hap ve iksirlere boşa para vermekle kalmazlar, ayrıca vebadan korunmak için aldıkları bu ilaçlarla kendilerini zehirleyip vücutlarını vebaya açık hale getirirler. ${ }^{99}$ Astroloji ve batıl inançlar halk arasında yaygınlaşır. Salgından önce vuku bulan alametlere, özellikle astronomik olaylara, gök cisimlerinin hareketlerine ilgi artar. Salgın, vebanın başlamasından aylar önce görülen kuyruklu yıldıza, gezegenlerin birleşimine atfedilir. ${ }^{100}$ Prokopios, 536 yllında gerçekleşen "korkunç bir alamet"ten bahseder: "Güneş tüm yıl boyunca ay gibi parlaklığını yitirdi ve fazlasıyla güneş tutulmasına benziyordu, çünkü saçtığı 1şınlar net değildi” ve "bu olayın meydana geldiği andan itibaren, insanlar ne savaştan, ne salgın hastalıktan ne de ölüme götüren” diğer felaketlerden kurtuldular. ${ }^{101}$ Boccacio ise vebanın belki gezegenlerin etkisiyle ortaya çıktığını belki de "günahlarımız için Tanrı tarafından gönderilen adil bir ceza" olduğunu söyler. ${ }^{102}$

\footnotetext{
${ }^{92}$ Defoe, A Journal, s.98-99.

${ }^{93}$ Defoe, A Journal, s.99.

${ }^{94}$ Boccaccio, Decameron, s.3.

${ }^{95}$ Defoe, A Journal, s.99.

${ }^{96}$ Defoe, A Journal, s.252-253.

${ }^{97}$ Defoe, A Journal, s.38-39.

${ }^{98}$ Defoe, A Journal, s.42.

${ }^{99}$ Defoe, A Journal, s.42.

${ }^{100}$ Defoe, A Journal, s.30; 36.

${ }^{101}$ Procopius, History, III \& IV, s.329.

102 Boccaccio, Decameron, s.1.
} 
Halk arasında çeşitli hurafeler yayılır. Efesli Yuhanna'ya göre, besbelli “iblisler insanları yoldan çıkarmak ve deliliklerine gülmek istiyorlardı" ki hastalığı atlatıp "hayatta kalanlar, üst katların pencerelerinden testi atar ve testiler aşağıda patlarsa ölüm şehirden kaçacaktır söylentisi" halk arasında yayılır: "Şayia bir mahalleden diğerine ve tüm şehre yayıldı ve herkes bu aptallığa yenik düştü”, öyle ki ölümden kurtulanlar "evlerinde tek başlarına ya da gruplar halinde azimle testi kırarak ölümü kovaladıklarından” üç gün boyunca sokağa çıkamazlar. ${ }^{103}$ Atina' da eski kehanetler hatırlanır, ve salgına uyacak şekilde yeniden yorumlanır. ${ }^{104}$ Fas'ta ise karşılaştıkları herkesi vebayla devirmeye çalışan ölülerin varlığına inanılır. ${ }^{105}$

Efesli Yuhanna ve Prokopios, vebaya yakalanmadan önce potansiyel kurbanların gördükleri halüsinasyonlardan, rahatsız edici alametlerden bahsederler. Yuhanna, vebanın bir ülkeden diğerine geçerken birçok kişiye ellerinde bronz sopalarla, bronz tekneler içinde denizde seyahat eden başsız insanlar şeklinde göründüğünü yazar. ${ }^{106}$ Prokopios'a göre hastalığa yakalananlar yakalanmadan önce görsel ve işitsel halüsinasyonlar deneyimliyordu. Prokopios vebadan etkilenen birçok kişinin, “insan kılığına girmiş doğaüstü varlıklar” gördüğünü ve insan şeklindeki bu hayaletlerin kendi vücutlarına çarptıktan hemen sonra hastalığa yakalandıklarına inandıklarını söyler. Bu iblislerden kaçmak için kendilerini odalarına kapatıp hiçbir şekilde dışarı çıkmayan ve gelenin bu hayaletlerden biri olabileceği endişesiyle, kapılarını çalan kim olursa olsun, duymamış gibi davrananlardan ve uykularında kendilerinin de ölüler kütüğüne kaydedildiğini söyleyen sesler duyduklarını iddia edenlerden bahseder. ${ }^{107}$ Hastalığa yakalananların bir kısmında derin bir koma hali galip gelirken bir diğer kısmında ise çılgın bir taşkınlık ortaya çıkar. Komanın etkisi altında olanlar sürekli uyurken, "hezeyana yakalananlar uykusuzluktan muzdaripti ve çarpık bir hayal gücünün kurbanı olarak insanların kendilerini yok etmek için üzerlerine geldiklerinden şüpheleniyor" ve kaçmaya çalışıyorlard $1 .{ }^{108} \mathrm{De}$ foe, buluttan çıan bir elin tuttuğu alev saçan bir kılıç, havada gezinen tabutlar, cenaze arabaları, gömülmemiş ceset yığınları gördüklerini ısrarla iddia edenlerle karşılaşır. ${ }^{109}$

\section{Issızlık ve O̊lülerin Kalabalığı}

İstanbul'da tüm işler durma noktasına gelir, alım satım durur, "tüm dünyevi zenginliklerle" donatılmış dükkanlar kapanır. ${ }^{110}$ Şehir adeta hareketsizdir. Bir zamanlar kalabalık olan bu kentte "1ssızlık ve boşluk bir günden diğerine" artar. ${ }^{111}$ İmparatorluğa hükmeden şehirde resmi kıyafetli birini görmek neredeyse imkansızdır, zira herkes kendi evinde gündelik kıyafetleriyle sessizce oturup beklemektedir. ${ }^{112}$

\footnotetext{
103 "John of Ephesus".

${ }^{104}$ Thucydides, The History, s.123.

${ }^{105}$ Jackson, An Acount, s.177.

106 "John of Ephesus".

${ }^{107}$ Procopius, History, I \& II, s.455-457.

${ }^{108}$ Procopius, History, I \& II, s. 459.

${ }^{109}$ Defoe, $A$ Journal, s.33.

110 "John of Ephesus".

111 "John of Ephesus".

112 Procopius, History, I \& II, s.473.
} 
Yiyecek tedariki yapılamaz olur, kıtlık genellikle her şeyin bol olduğu kenti tehdit eder. ${ }^{113}$

Floransa'nın da sokakları boşalmıştır. Şehirdeki loncaların hepsi faaliyetlerini durdurur: "Bütün dükkanlar kapatıldı, tavernalar kapatıldı; sadece eczacılar ve kiliseler açık kald»"114 diye yazar Stefani.

Önce madenlerin, sonra okul ve kiliselerin kapatıldığı ve tüm toplantıların iptal edildiği ${ }^{115}$ Gibbsville'de de sokaklar o kadar 1ssızdır ki salgın adeta "yeni bir tür bayram" getirmiş gibidir. Ama sessizliğe bürünmüş sokaklarda ne bayram günlerinin telaşı ne de iş günlerinin faaliyeti gözlenir. ${ }^{116}$

Salgın ilerledikçe Londra'da da sokaklar ıssızlaşır, hareketli ticaret merkezleri boşalır, iki dükkandan biri kapanır. ${ }^{117}$ Pepys'in sokaklarda gördüğü az sayıdaki kişi ise yarı ölü halde dolaşan "dünyayı terk etmiş insanları" andırır. ${ }^{118}$ Londra bir hayalet şehre dönmüş, ürkütücü bir sessizliğe bürünmüştür: "Tanrım! Sokaklar ne kadar boş ve melankolik, sokaklarda o kadar çok ... zavallı hasta var ki; ve yürürken duyduğum pek çok hüzünlü hikaye; herkes ya bir ölüden veya hasta bir adamdan söz ediyor ve burada şu kadar, orada bu kadar kişi var diyor." 119 Nehirde teknelerin görünmediği, Whitehall Sarayı Caddesi boyunca çimenlerin öylesine uzadığı ve sokaklarda biçare zavallılardan başka kimsenin olmadığı üzücü zamanlardır bunlar. ${ }^{120}$ İnsanların bakışına da söylemine de ölüm hükmetmektedir:"121 "En yakın akrabalarının ölmekte olduğu ya da henüz öldüğü evlerin pencere ve kapılarındaki kadınların ve çocukların çı̆̆lıkları, biz sokaklardan geçerken o kadar sık duyulacaktı ki." ${ }^{22}$ H. F. de boş bir sokakta bir kadının pencereyi açıp "üç korkunç çığlık” attığını duyar: “Ah! Ölüm, ölüm, ölüm!”123 Bu çığlıkların ardından sokak tekrar sessizliğe bürünür. Yasın sesinden başka ses duyulmaz olmuştur. Londra'da "bütün sokaklar terk edilmiş görünüyordu” der Defoe, "boş evlerde kapılar açık bırakılmış, insanların kapatmasına muhtaç pencereler, rüzgarla paramparça olmuştu”. ${ }^{124}$ Korkularına teslim olup, umutlarını kaybeden insanları "evrensel bir 1ssizlık"125 hissi kaplar.

Londra'nın sokakları eski canlılı̆̆ını yitirmesine yitirmiştir ancak salgının en fazla etkilediği kesim olan yoksullar hala sokaklardadır: "Vebanın esas olarak yoksullar arasında olduğu itiraf edilmelidir" der Defoe'nun anlatıcısı H. F. ${ }^{126}$ Buna rağmen, salgına karşı en korkusuz ve gözü pek olanlar yine onlardır; "vahşi bir cesaretle" hiçbir tedbir almadan çalışabilecekleri her türlü işin peşinden giderler. Hastalara

\footnotetext{
${ }^{113}$ Procopius, History I \& II, s.471.

${ }^{114}$ Stefani, "The Florentine".

115 O'Hara, The Doctor's, s.8.

${ }^{116}$ O'Hara, The Doctor's, s.37.

117 Pepys, The Diary, s.335.

118 Pepys, The Diary, s. 337

119 Pepys, The Diary, s.350.

${ }^{120}$ Pepys, The Diary, s.344.

${ }^{121}$ Pepys, The Diary, s.338.

${ }^{122}$ Defoe, A Journal, s.33.

${ }^{123}$ Defoe, A Journal, s. 102.

${ }^{124}$ Defoe, A Journal, s.208.

${ }^{125}$ Defoe, A Journal, s.208.

${ }^{126}$ Defoe, A Journal, s.112.
} 
bakmak, karantinadakilere bekçilik etmek, hastaları veba hastanelerine, ölüleri mezara taşımak gibi hastalık açısından en riskli işleri yaparlar. ${ }^{127}$ Cesaretleri, ekonomik zorunlulukların çaresizliğinden doğmaktadır.

Floransa'da da veba en çok, gidecek yerleri ve olanakları olmayan fakirleri vurur. ${ }^{128}$ Benzer şekilde O'Hara, Pennsylvania'nın kömür madenlerinde çalışan ve genç yaşta "madenci astımından" mustarip olanların "bu gizemli yeni hastalığa" karşı hiç şanslarının olmadığına dikkat çeker. İstanbul'da da önce fakirler ölür: “Tanrı'nın merhameti kendini her yerde fakirlere gösterdi, çünkü önce onlar öldü." ${ }^{22}$ Efesli Yuhanna fakirlerin salgının başında ölmesini ilahi bir rahmet olarak görür, zira salgının ilk aşamalarında ölüler hala kurallara uygun gömülürken, ilerleyen günlerde artan ölüm oranları geleneksel cenaze törenlerini olanaksız kılar, tüm gömü adetleri göz ardı edilir. Başlarda ölenlerin cenazelerine katılan akraba ve uşaklar, salgın hızını arttırdıkça törenlere katılmaktan vazgeçerler. Ölülere ne cenaze alayı ne de ilahiler eşlik eder. ${ }^{130}$ Atina'da cenaze törenlerinin kuralları altüst olmuştur; ölüler "mümkün olan her şekilde" gömülür: Birçoğu, uygun gereçlerin yokluğundan "en rezil defin" yolunu seçerler, kendi ölülerini yabancılar için hazırlanan odun yığının içine atıp ateşe verirler veya "taşıdıkları cesedi yanmakta olan bir diğerinin üzerine firlatıp" giderler. ${ }^{131}$

İstanbul'da cesetlerin imhası kısa sürede ciddi bir sorun haline gelir. Salgının zirvesinde insanları evlerinden çıkaran tek şey, cesetlerin ortadan kaldırılması gerekliliğidir: "Hepsinden acil olan şey hala hayatta olanların evlerindeki cesetleri çıkarması" ve sokaktaki cesetlerin deniz kıyısına götürülüp teknelere doldurulmasıydı. Cesetleri denize attıktan sonra tekneler kalanları almak için geri dönüyordu. İçlerinden cerahat akan sayısız ceset kıyı boyunca yığılmıştı. ${ }^{132}$ Ödenen yüksek ücrete rağmen, cesetleri taşıyıp köpek leşleri gibi çukurlara atacak birini bulmak neredeyse imkansızdır. İnsanlar "ceset kokusu ve köpekler tarafından yenen bedenler" sebebiyle sokağa çıkmaya korkar olmuştur. Gömülmeden bırakılma ya da leş yiyicilere yem olma endişesi o kadar büyüktür ki, kimse üzerinde kimlik etiketi olmadan dişarıya çıkmaya cesaret edemez. ${ }^{133}$

Mezarlıklar yetersiz kalınca cesetler önce şehrin dört bir yanında kazılan hendeklere gömülür: "[Cesetler] yer kıtlığından birbirine bastırıldı, ayaklarla ezildi ve bozulmuş üzümler gibi çiğnendi" ve baş aşağı hendeklere atıldı; "Soylu erkekler ve kadınlar, yaşlı erkekler ve kadınlar, genç erkek ve bakireler, genç kızlar ve bebekler" atıldıkları çukurlarda parçalandılar. ${ }^{134}$ Hendekler de yetersiz kalınca Galata'daki surların kulelerinin çatıları sökülür, cesetler gelişigüzel bu kulelerin içine atılır. Kuleler dolunca çatıları tekrar kapatılır. Rüzgarın Galata bölgesinden estiği günlerde, insanları kederlendiren kötü bir koku şehri kaplar. ${ }^{135}$ Aynı koku Floransa’nın havasına

\footnotetext{
${ }^{127}$ Defoe, A Journal, s.112-113.

${ }^{128}$ Boccaccio, Decameron, s.4.

129 "John of Ephesus".

${ }^{130}$ Procopius, History, I \& II, s.469.

131 Thucydides, The History, s.122.

132 "John of Ephesus".

133 "John of Ephesus".

134 "John of Ephesus".

${ }^{135}$ Procopius, History, I \& II, s. 467-8.
} 
da nüfuz eder. ${ }^{136}$ Ölüler şehrin tenha ve kasvetli sokaklarında büyük bir kalabalık oluştururlar. Floransa'da gece ve gündüz çok sayıda insan ölür; evlerinde ölenleri ancak çürüyüp kokmaya başlayınca fark eden komşuları, kapıların önüne taşıyıp sokağa bırakırlar. ${ }^{137}$ Londra sokakları da orada burada yatan cansız bedenlerle doludur; cesetleri gören herkes yolunu değiştirir. ${ }^{138}$ Pepys, vebadan ölmüş birinin tabutunun sokakta bekletildiğini ve kimsenin yanına yaklaşmaması için başında bir nöbetçinin görevlendirildiğini görünce "bu hastalık bizi birbirimize karşı köpeklerin birbirlerine karşı olduğundan daha acımasız yapıyor" der. ${ }^{139}$ Cesetler bazen cenaze arabaları gelip toplasın diye sokağa bırakılır, bazen pencere veya balkondan iple aşağı sarkıtılır. ${ }^{140}$ Defoe "Ölülerinizi dışarı çıkarın!" çığlıkları eşliğinde ceset yüklü arabaların ürpertici ilerleyişine tanıklık eder. ${ }^{141}$ Cansız bedenleri taşıyan arabalar kilise avlularını toplu mezarlara dönüştürür. ${ }^{142}$ Salgının en tepeye ulaştığı dönemde, ölüler için kimse çan çalmaz, yas tutup ağlamaz, yas kıyafeti giymez, tabut dahi kullanılmaz. ${ }^{143}$ Londra'da alınan tedbirler kapsamında, cenazelere komşu ve arkadaşların katılması yasaklanır; defin işlemi ya güneş doğmadan önce ya da güneş battıktan sonra yapılacak ve mezarlar gerektiği kadar derin kazılacaktır. ${ }^{144}$ Floransa'da cenazeye katılma yasağ 1 yoktur; ancak burada da ölüler neredeyse tek başlarına gömülür. Cenazeye ne gözyaşları ne sevenleri ne de mumlar eşlik eder. İşler öyle bir noktaya gelir ki ölüye ancak hayvanlara gösterileninki kadar özen gösterilir. ${ }^{145} \mathrm{Ne}$ zaman ve hangi şartlar altında bu dünyadan ayrıldığ ${ }_{1}$ bilinmeyen pek çok insan bu şekilde gömülür.

Sayılar arttıkça ölüleri gömecek yer bulmak Floransa'da da sorun olur. O kadar çok ceset gelir ki mezarlıklar yetersiz kalır. Muazzam sayıdaki ölüyü tek tek gömmek imkansız olduğundan yüzlercesi, gemilerde yan yana ve sıra sıra dizilen mallar misali, aynı anda gömülür. ${ }^{146}$ Kiliselerde, cemaatlerinin büyüklügüne göre geniş ve derin hendekler kazılır, cesetler gece sırtlarda taşınarak bu hendeklere atılır. Ertesi sabah cesetler toprakla kaplanıp bir üst sıraya geçilir; Stefani'nin deyişiyle, "bunların üstüne daha fazla ceset kondu, bunların üzerine de biraz daha toprak; tabaka üstüne tabaka eklediler, tıpkı lazanyaya kat kat peynir konduğu gibi." ${ }^{147}$ Eski ve Yeni Fes şehirlerinde ölüm oranları o kadar artar ki cesetleri tek tek gömmeye vakit olmaz; defin konusundaki tüm usuller göz ardı edilir, ölü bedenler toplanıp büyük çukurlara atılır ve bu çukurlar dolduğunda üzerleri toprakla örtülür. ${ }^{148}$ Hindistan'da da Ganga nehri terkedilmiş cesetlerle dolup taşar. ${ }^{149}$

\footnotetext{
${ }^{136}$ Boccaccio, Decameron, s.3.

${ }^{137}$ Boccaccio, Decameron, s.4.

${ }^{138}$ Defoe, A Journal, s.100.

${ }^{139}$ Pepys, The Diary, s.337.

${ }^{140}$ Defoe, A Journal, s.219.

${ }^{141}$ Defoe, A Journal, s.65.

${ }^{142}$ Defoe, A Journal, s.219.

${ }^{143}$ Defoe, A Journal, s.208.

${ }^{144}$ Defoe, A Journal, s.57.

${ }^{145}$ Boccaccio, Decameron, s.5.

${ }^{146}$ Boccaccio, Decameron, s.5.

${ }^{147}$ Stefani, "The Florentine".

${ }_{148}$ Jackson, An Acount, s.170.

${ }^{149}$ Nirala, A Life, s.83.
} 


\section{Ahlak ile Ahlaksızlık Arasında}

Salgınların ahlaki ve sosyal etkileri de olur; bazıları dine döner, bazıları dinden çıkar. Atina'da birçok kişi, daha önce ancak bir köşede, başkalarından gizli yapmaya yeltendikleri şeyleri, artık soğukkanlı bir cesaretle herkesin gözü önünde, çekinmeden yapar. ${ }^{150}$ Ölen zenginlerin mal ve mülklerinden yararlanan yoksullar, hayatlarının ve dolayısıyla yeni edindikleri servetlerinin kısa ömürlü olacağına inanarak hiç ertelemeden anında kar ve zevke odaklanmanın makul, onurlu ve yararlı olduğunu düşünürler. ${ }^{151}$ Tanrılardan ya da insan yasalarından korkmanın herhangi bir kısıtlayıcı gücü kalmamıştır çünkü dindar olan da olmayan da hastalığa yakalanıyor, hastalık iyi ile kötüyü ayırt etmiyordur. ${ }^{152}$ Salgın hem şiddetli hem de acımasızdır. Kimse suçlarının cezasını ödemek zorunda kalacak kadar uzun yaşayacağını düşünmez. İnsanlar daha ziyade, önceden kararlaştırılmış çok daha ağır bir ceza hükmünün -ölüm cezası hükmünün- üzerlerinde asılı olduğunu ve infaz edilmeden önce, hayattan biraz zevk almanın akıllıca olduğunu düşünmek eğilimindedir. ${ }^{153}$ Floransa'da da "hem ilahi hem de insan yasalarının" otoritesi fiilen ortadan kalkar. ${ }^{154}$ Aniden boşalan şehirde evlerin çoğu ortak mülkiyet haline gelir ve yabancılar onları gerçek sahipleri gibi kullanır. ${ }^{155}$ Ölülere ve ölmekte olanlara yaptıkları hizmetlerden büyük ölçüde kar eden bir “akbabalar” sınıfı ortaya çıkar. ${ }^{156}$ Hasta bakımı kadar hastaların yediği tatlı, şeker ve şekerlemelerin, kümes hayvanları ve yumurtanın fiyatı da artar; balmumu bulmak neredeyse imkansız ve çok az kişinin karşılayabileceği kadar pahalı hale gelir: "Floransalıların her daim cenazeler için yaptıkları kibirli gösterişe hükümet, cenazelerde ikiden fazla mum taşınmasını yasaklayarak, dur demeseydi bir kilo balmumunun fiyatı" daha fazla yükselirdi. ${ }^{157} \mathrm{Ba}$ harat tüccarları ve mezar kazıcıları artan ölü sayıları karşısında yetersiz kalan tabut sehpası, tabut örtüsü ve tabut yastığını fahiş fiyatlarla satarlar; yas kıyafetlerinin fiyatları on kat artar. ${ }^{158}$ Gibbsville'de de cenaze levazımatçıları vurgunculuğa başlar. "Salgın öncesi maun tabutlar için istedikleri parayı" şimdi "kaba kutular" için talep ederler. ${ }^{159}$

Hem Floransa'da hem de Londra'da dolandırıcılar, sahtekarlar, şarlatanlar paniğe kapılmış insanların kaygılarından yararlanmak için türlü yollara başvururlar. Vurguncular, sahte doktorlar, şifacılar ortaya çıkar, sahte virüs ilaçları, "mucize" tedaviler dolaşıma girer. Londra' da "bu korkunç zamanda bile" çok sayıda soygun ve kötülük yapılır. Bazılarının açgözlülüğünün haddi hududu yoktur; çalmak ve yağmalamak için her türlü tehlikeyi göze alırlar, tüm sakinlerinin öldüğü evlere bulaş riskine aldırmaksızın girip ölülerin elbiselerini, yatak örtülerini çalarlar. ${ }^{160}$ Proko-

\footnotetext{
150 Thucydides, The History, s.122.

151 Thucydides, The History, s.122.

152 Thucydides, The History, s.122-123.

153 Thucydides, The History, s.123.

154 Boccaccio, Decameron, s.3.

155 Boccaccio, Decameron, s.3.

156 Stefani, “The Florentine”.

${ }^{157}$ Stefani, "The Florentine".

${ }^{158}$ Stefani, "The Florentine".

${ }^{159}$ O'Hara, The Doctor's, s.35.

${ }^{160}$ Defoe, A Journal, s.105.
} 
pios’a göre vebanın dehşeti, kendi ölümlerinin eli kulağında olmasından korkanları ahlaksızlıktan dindarlığa döndürür: "Geçmişte kendilerini hem utanç verici hem de adi arayışlara adamaktan zevk alanlar günlük yaşamlarının ahlaksızlığından siyrilıp dinin gereklerini özenle yerine getirdiler." ${ }^{161}$ Bununla birlikte, hasta olup iyileşenler, lanet kendilerini terk edip başka insanlara uğradığında "artık güvende olduklarını düşünerek" alçaklıklarına geri döner, "her türden kötülük ve kanunsuzlukta kendilerini aşarak" eskisinden daha da ahlaksız hale gelirler. ${ }^{162}$ Fas'ta da eskiden fakir olan zenginleşir, ata nasıl binileceğini bilmeyenler at sahibi olur. Halkın alaycı bir şekilde sonradan görme "mirasçılar" adını taktığı bu kesime her yerde rastlanır. ${ }^{163}$ Koyun ve sığırlar tarlalarda sahipsiz kaldıkları halde adalet duygusu ile yağma edilmez, zira salgın insan itaatsizliğine karşı Tanrı'nın bir yargısı olarak görüldüğünden pek çok kişi cennete hazırlık olarak görür bu süreci. Bir dahaki sefere sıranın kendilerine geleceğine inananlar işlerini düşünmez olur ve dünyevi kaygıları bir kenara bırakırlar. ${ }^{164}$

\section{İkinci Dalga}

İnsanlar normal hayata dönmek için can atmaktadır. Eylül'de ölüm oranları düşünce, doktorların aksi yöndeki tavsiyelerine rağmen, Londralılar her türlü önlemden vazgeçip veba öncesi yaşamlarına dönerler. Hekimler, halkın bu düşüncesiz davranışına, hastalığın daha ölümcül ve tehlikeli geri dönüşü tehlikesine dikkat çekerek, "tüm güçleriyle" karşı çıkarlar, bu yöndeki yazılı talimatlarını şehrin ve banliyölerin her yerine yayarak halka "ihtiyatlı davranmaya devam etmelerini ve hastalıktaki azalmaya rağmen davranışlarında hala son derece dikkatli olmalarını tavsiye" ederler. ${ }^{165}$ Ancak "cüretkar yaratıklar" öylesine mutludurlar ki ölüm tehlikesinin geçmediğine onları ikna etmek olanaksızdır: "Dükkanlarını açtılar, sokaklarda dolaştılar, iş yaptılar ve karşılaştıkları herkesle, işleri olsun veya olmasın, sağlıklarını sorgulamadan ya da onlardan gelecek herhangi bir tehlikeden endişe duymadan rahatlıkla sohbet ettiler." 166 Toplum erken açılmış, tedbirlerden erken vazgeçilmiştir. Bu durum hastalı̆̆ın yeniden alevlenmesine yol açar: "Bu tedbirsiz, aceleci davranış, büyük bir özen ve dikkatle kendilerini kapatmış, deyim yerindeyse, tüm insanlıktan elini ayağını çekmiş" ve kendilerini hastalıktan korumuş olan birçok kişinin canına mal olur. ${ }^{167}$ Hastalığın azaldığına dair söylenti kırsal bölgelere yayıldığında, "Londra'dan bu kadar uzun süre uzakta kalmaktan öylesine yorulmuş ve geri dönmeye son derece hevesli olan insanlar, korkmadan ve sonuçlarını öngörmeden" şehre akın etmekle kalmaz "sanki tehlike ortadan kalkmış gibi sokaklarda boy göstermeye başlarlar."168 5 Ocak 1666'da Pepys, günlügüne "Bir asilzadenin arabasının şehre geldiğini görmek ne güzel! Şehrin yeniden insanlarla dolu olduğunu görmek çok hoş; ve her ne kadar birçok yerde yedi veya sekizi ve

\footnotetext{
${ }^{161}$ Procopius, History, $I$ \& II, s. 469.

162 Procopius, History, I \& II, s.471.

163 Jackson, An Acount, s.170-171.

164 Jackson, An Acount, s.160.

165 Defoe, A Journal, s.273.

${ }^{166}$ Defoe, A Journal, s.273-4.

${ }^{167}$ Defoe, A Journal, s.274.

${ }^{168}$ Defoe, A Journal, s.274.
} 
daha fazlası kapalı olsa da dükkanlar açılmaya başladı" notunu düşer. ${ }^{169}$ Ertesi gün salgın nedeniyle Londra'yı terk etmiş olan Pepys'in eşi de şehre döner. Ancak tehlike geçmemiştir. Ocak ayının ikinci haftasında salgın kurbanlarının sayısında artış yaşanır. ${ }^{170}$ Yine de sayılardaki dalgalanmalara ve bu dalgalanmaların yarattığı endişelere rağmen salgın ölümleri eskiye kıyasla dramatik şekilde düştüğü için hayat normale döner. Pepys veba başladığından beri ilk kez eski uğrak yerlerine gidip gelmeye başlar, eski arkadaşlarıyla buluşur, kiliseye gider. ${ }^{171}$ Fas'ta da benzer bir durum yaşanır. Ekim sonunda Mogodor'da salgın durur. Çevre illerdeki ölümlere rağmen hayat normale döner. Ancak Haha'dan Berberilerin şehre gelip ölen akrabalarının kıyafetlerini satmaya başlamalarıyla salgın Kasım'ın ilk yarısında yeniden alevlenir. ${ }^{172}$ Şehirden kaçanlar, salgının zayıflamış görünümüne aldanıp geri dönünce hastalığa yakalanıp hayatlarını kaybederler. ${ }^{173}$

\section{Sağlık Çalışanları}

Salgınlarda en fazla etkilenen kesim sağlık çalışanlarıdır: Atina'da hastalarla en fazla temasta bulunan kişiler olan sağlıkçılar arasında ölüm oranı çok yüksektir. ${ }^{174}$ Londra' da "Westminster'daki tüm hekimler ve bir eczacı dışında tüm eczacılar" hayatını kaybeder; Pepys' in kendi doktoru da vebadan ölür. ${ }^{175}$ Floransa'da doktor ölümlerinden dolayı hekim bulmak neredeyse imkansız hale gelir. Bulunabilenler ise çağrıldıkları evlere girmeden önce büyük meblağlar talep ederler. İçeri girdiklerinde bulaş korkusundan hastanın nabzını yüzlerini başka tarafa dönerek kontrol ederler. ${ }^{176}$

Salgını, hekim babasıyla birlikte yaşayan John O’Hara'nın doktorlar hakkındaki gözlemleri daha detaylıdır: "Babam 1918 sonbaharında bir sabah saat dörtte eve geldi ve oturma odasında bir kanepeye yığıldı. Kahvaltı yapıp -henüz kapanmamış olan- okula gitmek için yaptığımız hazırlıkların gürültüsünü duyana kadar uyanmadı. Uyandığında ise dışarı çıkıp çalışır durumda bıraktığı arabanın motorunu kapattı, sonra yatağına gitti ve yaklaşık iki gün uyudu. O sabaha kadar, neredeyse üç gündür ara vermeden iki saatten fazla uyumamıştı." 177 Salgından önce "günde kırk hastaya" bakan babası "salgınla beraber kaç hastaya baktığını hatırlamıyordu bile." ${ }^{178}$ Salgının zirvesinde Doktor Malloy uyumak için ofisinin kapısını kilitleyip yere ya da ameliyat masasına uzanır, kendisini zorla götürmek için gelecek ya da tehdit edecek hasta yakınlarına, "vahşi adam veya kadınlara" karşı korunmak için yanına bir tabanca koyar. ${ }^{179}$ İşini geçici olarak devralacak genç doktor kalmamıştır; onlar da salgın nedeniyle, bir günde, normal zamanlarda bir ayda gördüklerinden

\footnotetext{
${ }^{169}$ Pepys, The Diary, s.364.

${ }^{170}$ Pepys, The Diary, s.366.

${ }^{171}$ Pepys, The Diary, s.368.

${ }^{172}$ Jackson, An Acount, s.163.

${ }^{173}$ Jackson, An Acount, s.169.

${ }^{174}$ Thucydides, The History, s.119.

175 Pepys, The Diary, s.350; 337.

${ }^{176}$ Stefani, "The Florentine".

177 O'Hara, The Doctor's, s.6.

${ }^{178}$ O'Hara, The Doctor's, s.7.

${ }^{179}$ O'Hara, The Doctor's, s.6-7.
} 
çok daha fazla hasta gördüklerinden, iş yükleri yaşlllarınki kadar yoğundur. ${ }^{180} \mathrm{Ba}$ bası stres, uykusuzluk ve yorgunluktan bitap düşünce bir tıp öğrencisi olan Doktor Myers geçici olarak onun yerini alır. Oğul James de doktorun şoförlüğünü üstlenip onunla birlikte hastaları ziyarete gider. Doktor Malloy'un hastalarıyla kişisel ilişki geliştirmesine izin veren eski tip ev ziyareti tarzı, salgınla birlikte yerini acil hastanelere ve anonim ama geniş çaplı sağlık hizmetlerine bırakır. Barlar, madenciler ve aileleri için derme çatma doktor muayenehanelerine dönüştürülür. Doktor Myers, düzinelerce madenci ve madenci eşinin kendisini görmek için bir araya geldiği barları ziyaret eder. Buralara girerken başlarda, hem kendisi hem de James, burun ve ağızlarını kapatan maske takarlar. Ama gazlı bez dudaklarına yapışınca James maskeyi takmaktan vazgeçer. Gerektiğinde maskeyi çıkarıp yeniden takmak zahmetlidir; "grupta hiç kimse maske takmıyorken yüzünüzde maske ile yürümek oldukça aşağılayıcı"181 olduğundan doktor da maske takmayı bırakır. Salgını yönetmek kolay değildir. Sağlık personeli eksikliği, yetersiz ilaç tedariki hastaların tedavi edilmesini olanaksız kılarken, bilinen tehlikesine rağmen engellenmesi zor kalabalıkların bir araya gelmesi de salgının hızını arttırır. Hastalar doktoru görmek veya yakınları için tıbbi tavsiye almak amacıyla sıraya girerler. Ailelerinde o kadar çok hasta vardır ki doktora gelen kişi her birinin semptomlarını tek tek tarif eder, Doktor Myers da hepsi için topluca reçete yazar. ${ }^{182}$ Doktorlar her hastaya üç dört soru sorup her vaka için ayrı reçete yazıyormuş gibi yaparlar. Sadece zamandan tasarruf etmek için değil, aynı zamanda eczanelerdeki ilaçlar yetersiz olduğundan hastaların neredeyse tamamına aynı reçeteyi yazarlar. ${ }^{183}$

\section{Sonuç Yerine}

Tarihin koronavirüs salgınını nasıl kaydedeceği, tanıklarının bu salgını nasıl kaleme alacağı henüz belli değil. Ancak gelecekte, bu kayıtları bu makaledeki tanıklıklarla birlikte ele alanlar, bilim, tıp ve teknolojideki büyük değişimlere rağmen salgınlar karşısında yaşanan insan çaresizliğinin, tedbirlilik ve tedbirsizliğinin, ümit ve ümitsizliğinin, yöneticilerin tutumlarının, sağlık çalışanlarının durumunun ve salgınların sınıfsallığının değişmediğini fark edeceklerdir.

\section{Kaynakça}

Boccaccio, Giovanni. The Decameron. New York: Printed for the Trade, 1899.

Defoe, Danie. A Journal of the Plague Year. Londra: Cassel, 1909.

Jackson, James Grey. An Account of Timbuctoo and Housa: Tewritories in the Interior of Africa., London: Longman, Hurst, Rees, Orme and Brown, 1820.

Nirala, Suryakant Tripathi, A Life Missspent. Çev. Satti Khanna. New York: Harper Perennial, 2016.

O'Hara, John. The Doctor's Son. New York: Library of America E-Book Classics, 2016.

Pepys, Samuel. The Diary of Samuel Pepys. Londra: Macmillan, 1905.

${ }^{180}$ O'Hara, The Doctor' s.8.

${ }^{181}$ O'Hara, The Doctor', s.35.

${ }^{182}$ O'Hara, The Doctor's, s.23-24.

${ }^{183}$ O'Hara, The Doctor's, s. 52. 
Procopius. History of the Wars, Books I \& II. Çev. H. B. Dewing, Londra: William Heinemann, 1914.

Procopius. History of the Wars, Books III \& IV. Çev. H. B. Dewing, Londra: William Heinemann, 1916.

"John of Ephesus describes the Justinianic Plague”. Haz., Roger Pearse. Erişim 3 Ocak, 2021. https://www.roger-pearse.com/weblog/2017/05/10/john-ofephesus-describes-the-justinianic-plague/.

Stefani, Marchione di Coppo. "The Florentine Chronicle". Fordham University. Erişim 8 Ocak, 2021. https://sourcebooks.fordham.edu/med/marchione.asp.

Thucydides. The History of the Peloponessian War. Çev. Henry Dale New York: Harper \& Brothers, 1878. 


\title{
Another Outbreak, A New Outbreak
}

\author{
ARUS YUMUL* \\ arus.yumul@bilgi.edu.tr \\ ORCID ID: 0000-0002-7783-2652
}

\begin{abstract}
In a sense, the world history is also the history of epidemics and pandemics that have caused huge numbers of deaths. Regardless of all positive advances brought about by vaccines and other scientific, medical and technological interventions and innovations, historical testimonies demonstrate that human vulnerability, despair and ways of dealing with disease and death, and - although they differ from one person to another-basic human reactions in the face of epidemics and death have not greatly changed for at least two thousand and five hundred years. This article deals with the testimonies of first-hand witnesses of the Athenian Plague (B.C.E. 430); Justinian Plague (541-542); Black Death, or the Great Plague (1347-1351); the Great Plague of London (1665-1666); the Plague of Morocco (1799), and the Spanish Flu (1918-1920). It shows that epidemics occurring in different times and under different conditions, by and large, lead to similar and comparable behaviour patterns.
\end{abstract}

Keywords: Epidemic, Literature, Responses, Precautions, Death

* Prof. Dr., İstanbul Bilgi University, Faculty of Social Sciences and Humanities, Department of Sociology. 